\title{
El trabajo extranjero en los escenarios de Buenos Aires a través de Caras y Caretas y Fray Mocho (1900 - 1920)
}

Fecha de recepción: 29/03/2020. Fecha de aceptación: 07/05/2020

\begin{abstract}
Resumen
Es imposible separar la comprensión de la historia argentina moderna de la presencia del enorme flujo de extranjeros que arribaron al país entre las últimas décadas del siglo XIX y las primeras del XX. La gran mayoría de los trabajadores extranjeros llegaban buscando una vida mejor, mejores posibilidades económicas y la inserción en la sociedad receptora. Sin embargo, otros llegaron a estas tierras solo de paso, por corto tiempo, muchas veces sin hablar el idioma ni conocer a nadie: entre estos trabajadores que padecieron la falta de leyes protectoras, los prejuicios de los nativos, los abusos de patrones y empresarios, la indiferencia de sus legaciones diplomáticas, etc., estaba el artista. El presente trabajo constituye una aproximación a la situación del artista que recorrió los escenarios teatrales de Buenos Aires entre 1900 y 1920, sus peripecias y desventuras como trabajador que -dada su extranjería- fueron más duras que las ya dramáticas de sus colegas locales
\end{abstract}

Palabras clave: extranjero, artista, trabajo, indefensión, abuso, Caras y Caretas, Fray Mocho

\section{Foreign Work on the Stages of Buenos Aires through Carasy Caretas and Fray Mocho (1900 - 1920)}

\begin{abstract}
It is impossible to separate the understanding of modern Argentine history from the enormous flow of foreigners who arrived in the country between the last decades of the 19th century and the first decades of the 2oth century. The vast majority of foreign workers came looking for a better life, better economic possibilities and insertion in the receiving society. However, others came to these lands only in passing, for a short time, often without speaking the language or knowing anyone: among these workers who suffered from the lack of protective laws, the prejudices of the natives, the abuses of employers, the indifference of their diplomatic legations, etc. was the artist. The present work constitutes an approximation to the situation of the artist
\end{abstract}


who toured the theater scenes of Buenos Aires between 1900 and 1920, his adventures and misadventures as a worker that, given his foreign status, were tougher than the already dramatic ones of his local colleagues

Keywords: Foreign, Artist, Work, Defenselessness, Abuse, Caras y Caretas, Fray Mocho

La gran corriente inmigratoria que llegó a la Argentina en las últimas décadas del siglo XIX se constituyó en uno de los fundamentales elementos que cambiaron la fisonomía étnica, social y - especialmente - cultural del país y a impulsarlo en la modernización. Sin embargo, junto con aquellas multitudes procedentes de Europa que se establecieron en estas tierras, se registró - sobre todo a fines de siglo - una fuerte inmigración temporaria que se convirtió en una fuente de mano de obra adicional. Entre 1870 y 1914 ingresaron a la Argentina casi ocho millones de personas, de las cuales casi cuatro millones y medio retornaron a sus países de origen. Estas cifras dan cuenta de la inmigración golondrina internacional, más significativa entre 1895 y 1914. Sin dejar de considerar la importancia de los trabajadores nativos, se puede afirmar que la Argentina moderna se conformó en el plano del trabajo con la inmigración extranjera (Lobato, 2000: 469 - 470).

Otra categoría de extranjeros llegaban y regresaban -y muchos terminaron quedándose definitivamente- con características propias: los artistas. Actores, artistas de varieté, cantantes, músicos, directores de orquesta, bailarines, artistas circenses, ventrílocuos, contorsionistas, magos y las más creativas variantes de una antiquísima forma de ganarse la vida: sobre un escenario.

De las condiciones laborales que padecieron entre 1900 y 1920, los problemas con que debieron lidiar en tierras extrañas de idioma muchas veces desconocido, sin ningún tipo de protección legal concreta ni de sus países de origen ni del nuestro, sin que su arte sirviera de protección contra estafas, abusos y miseria, casi no hay registros oficiales y muy pocos privados. Salvo las grandes estrellas de las que existen biografías y registros de la prensa de la época, de la inmensa mayoría de los que no alcanzaron la cima de la popularidad casi no ha quedado recuerdo alguno de cómo enfrentaron a la sociedad de su tiempo, a los prejuicios contra su profesión, a la amenaza de la trata de personas, al riesgo de vida ante la guerra, al racismo y la xenofobia - que traería luego el ascenso al poder de las dictaduras de derecha - como tampoco de sus propias miradas conflictivas sobre su profesión y-muchas veces - sobre la dificultad de verse a sí mismos como trabajadores y, por ende, luchar por sus derechos.

La historia oral - con los recaudos de su propia especificidad - y la prensa de la época son herramientas privilegiadas, y a menudo casi las únicas, para abrir una simbólica ventana al universo de aquellos trabajadores, varones, mujeres y también muchos niños que arribaron a la Argentina para trabajar en sus escenarios. El presente trabajo presenta un acercamiento al tema a través de las revistas Caras y Caretas y Fray Mocho, complementado también por entrevistas semi - estructuradas y otras publicaciones del período.

Las revistas ilustradas porteñas de principio de siglo representan para Gutman (2011: 153 -161) una de las manifestaciones más novedosas del rápido crecimiento y modernización de los medios de comunicación en la Argentina entre 1880 y 1920 . Este crecimiento incluyó el desarrollo del periodismo popular e informativo masivo, la edición de libros económicos para su venta en quioscos, la producción de folletos y folletines, las primeras experiencias del cine mudo, los discos y, más tarde, la radio. También el desarrollo de nuevos géneros como el tango, el sainete, el circo criollo y el folletín gauchesco, los cuales intentaron sintetizar las complejidades de una sociedad en rápida transición. 
Caras y Caretas, fundada en Buenos Aires por Eustaquio Pellicer y dirigida por José Sixto Álvarez, se publicó entre 1898 y 1941; existió una versión previa publicada en Uruguay entre 1890 y 1897 y dos versiones posteriores con el mismo nombre, en 1982 y en 2005, en Argentina. Según Rogers (2008: 13-18), Carasy Caretas es central para comprender la transformación cultural de aquella etapa inicial: perteneció al sistema misceláneo de magazine inspirado en publicaciones similares de Europa y Estados Unidos. Como empresa moderna colaboró con el surgimiento de una capa nueva de productores y favoreció la profesionalización literaria: sus colaboradores aportaron materiales breves y novedosos y fue la pionera en poner a disposición de los lectores - sin distinción de clase social, jerarquía cultural o identificación política - textos e imágenes del más variado tipo. Su carácter pionero también incluyó el precio bajo y la amplia audiencia, e introdujo los rasgos masivos del periodismo del siglo que comenzaba: estructura miscelánea, centralidad de la fotografía de actualidad, ficcionalización de las noticias, sustento en los anuncios y pago regular a los productores.

La revista incorporó, articuló y mezcló, casi sin restricciones, materiales e imágenes de diverso origen, al contrario de otras publicaciones tanto de la alta cultura letrada como de la cultura popular - comercial, que privilegiaban representaciones ligadas a una determinada identidad cultural y buscaban armar tradiciones relativamente cerradas y selectivas. Eujanian (1999: 98 -100) destaca el empleo de cromos y fotograbados que permitió mejorar el nivel técnico de la publicación, logrando la calidad necesaria para la edición de fotos e ilustraciones que formaban una de las zonas más sugerentes de Caras y Caretas.

Para Zubieta (2004: 510- 514), con Caras y Caretas emerge la prensa independiente moder$n a$, no facciosa o estrictamente política y se inicia un estilo en el que el lector debe primero informarse y luego reír; su nivel de difusión se reflejará en el progresivo aumento de sus páginas y en el hecho de pasar de ser de una publicación mensual a semanal. El carácter innovador está dado por la multiplicidad de secciones y temas abordados, por el nivel de sus exponentes y por haber sido la primera en pagar las colaboraciones literarias. Fue también pionera en iniciar varias áreas y temáticas: concursos que permitían al lector participar de la publicación. A través de una heterogeneidad explícita delineó con palabras y pinceladas las situaciones y personajes vinculados a la organización de la nueva sociedad que se perfilaba: para Rufinelli, en Caras y Caretas "el retrato de la Argentina de fin de siglo es una verdadera instantánea" (1968:11).

Fray Mocho fue una publicación semanal -aparecía los viernes- fundada en 1912 por parte del staff de Caras y Caretas - cuarenta y seis redactores y dibujantes - alejados por un conflicto originado aparentemente en su disconformidad con la línea editorial de esa revista. Entre los fundadores se contaban Carlos Correa Luna - ex director de Caras y Caretas - el reconocido dibujante José Cao, Luis Pardo, escritor costumbrista que hacía composiciones en verso sobre la actualidad bajo el seudónimo de Luis García, entre muchos otros prestigiosos colaboradores. En el diseño de Fray Mocho se instalaba, como en muchas publicaciones de la época, la tensión entre la línea gráfica inspirada en el diseño romántico - positivista del siglo XIX y el Art Nouveau o modernismo primero, y el Art Decó, luego: la inspiración en la naturaleza combinada con la nueva tecnología de la revolución industrial y las ideas de John Ruskin y William Morris democratizando la belleza o socializando el arte para su accesibilidad a toda la población, sin utilizar las técnicas de la producción masiva que minaban lo artesanal. Sus secciones fijas se referían también a diferentes temáticas: Teatros, De las Provincias, Notas Femeninas, Correo de Lectores, Folletines, Países del exterior, Vida cotidiana (local y extranjera). Fray Mocho se publicó en Buenos Aires hasta 1929.

Ambas publicaciones contaban con secciones dedicadas al espectáculo en las que, pese a destacarse las imágenes - muchas a página completa - con poco texto salvo 
excepciones, constituyen una fuente de datos que aportan una herramienta invaluable para la tarea - de ribetes a veces detectivescos - para desentrañar la realidad en una época lejana respecto de trabajadores que, si bien algunos protagonizaban en los escenarios, no detentaban derechos en la sociedad de su tiempo. A continuación, desarrollaremos algunos casos.

En 1895 , la cantante y artista excéntrica francesa Marie Videe - procedente de Marsella - llegaba a Buenos Aires para actuar con una troupe del mismo origen, entre las numerosas variedades presentadas por el Teatro Casino. Marie no hablaba español ni conocía a nadie en la ciudad; como alguno de sus compañeros del teatro comenzó a almorzar en una fonda económica de la calle 25 de Mayo. Al cabo de cierto tiempo, lo reducido de sus ingresos como artista le hizo difícil pagar las comidas en la fonda y aceptó la propuesta de la propietaria de cantar una noche ante los comensales a cambio de los almuerzos de esa semana. De algún modo, llegó a oídos de la empresa del teatro y fue despedida inmediatamente, considerando que había faltado a las obligaciones del contrato, pese a que éste no contenía cláusula alguna de exclusividad.

Sin medios, sin conocer el idioma y sin nadie a quién recurrir en un país extraño - sus compañeros de troupe la habían abandonado y regresado a Francia - Marie se pierde en la ciudad durante años sin poder volver a los escenarios. En el $\mathrm{N}^{\circ}$ del 3 de agosto de 1901 de Caras y Caretas se revela su último destino: en una nota de tres páginas se explicaba la obra llevada adelante por el Asilo de Mendigos de Buenos Aires, institución entonces dependiente de la municipalidad y atendida por las Hermanitas de los Pobres, congregación religiosa dedicada a la atención de la vejez desvalida; en efecto, se brindaba casa y comida a los pobres e indigentes de la ciudad. En una foto marginal de la nota aparecía la asilada María - su nombre ya había sido castellanizado - Vedee, una antigua cantatrice francesa que daba lecciones de canto a sus compañeros. Algunos detalles de su historia quedaron registrados en los archivos de la congregación religiosa, que trataba de obtener datos de la procedencia y las circunstancias de sus asilados, muchos de ellos inmigrantes extranjeros.

Mucho menos conocidas son las azarosas circunstancias de numerosos artistas extranjeros de habla alemana (alemanes y austro - húngaros), que pasaron por el país en el período comprendido entre 1890 y 1930: el reducido número de inmigrantes de aquellas nacionalidades que llegaban a Argentina - en comparación con la mayoritaria corriente proveniente de Italia y España -, debido a la casi infranqueable barrera del idioma (esto no se aplica respecto de los cantantes, músicos y directores de orquesta), hizo que sus tribulaciones laborales fueran generalmente sólo conocidas por las sociedades germánicas de socorros mutuos, sus iglesias -en 1870 existían ocho asociaciones culturales alemanas y cuarenta en 1914 de índole religiosa, cultural y escolar. Véase Saint Sauveur Henn, A. (2017)-, y por compatriotas ya insertos en la sociedad receptora desde el siglo XIX.

Un caso sirve como ejemplo: en agosto de 1901, la Sociedad Dramática Alemana invitaba a una de las dos funciones que se representarían en el Teatro Odeón de la comedia en tres actos Fleschman als Erzierher, protagonizada por el conocido actor alemán Rudolf Schildkraut - casualmente en Buenos Aires - con veintiún actores en escena, que se había puesto en escena frente al Kaiser en el Teatro de la Comedia de Hamburgo. En la primera función, con el teatro colmado de público de la colonia alemana y austro - húngara, Franz Graber, actor de 31 años procedente de Berlín, sufre una caída en escena y una fractura de tobillo. Graber fue trasladado al Hospital Alemán, atendido por una fractura expuesta y quedó internado en la institución: al no presentarse a la segunda función, fue despedido. Al retornar la compañía a Berlín, quedaba varado en Buenos Aires sin recursos, con su salud afectada y sin conocer el idioma. Por intermedio de compatriotas del personal médico - que organizaron una colecta en su 
beneficio - intentó una repatriación vía diplomática que no tuvo éxito y, finalmente, se dio aviso a la Sociedad Alemana de Socorro a Enfermos (Deutscher Krankenverein) que acudió en su ayuda y le consiguió empleo en Buenos Aires como dependiente en una firma alemana, después de recomendarle expresamente que ocultara el hecho de que era actor. Franz Graber vivió once años en la Argentina, padeció una cojera permanente y nunca retomó la actuación.

El año del Centenario - 1910 - atrajo a muchos artistas europeos que participaron en los espectáculos que entretuvieron al público argentino y a los invitados extranjeros a los importantes festejos organizados por el gobierno nacional. El Imperio Alemán tuvo una significativa presencia en tres de las cuatro grandes exposiciones sobre la producción: agropecuaria, transporte, higiene y arte. Fue representado por una importante figura del ejército imperial: el mariscal de campo general barón Wilhelm Leopold Colmar von der Goltz (1843 - 1916) (Lutge, W. y Hoffmann, W. y otros (2017), p. 357-358). Actores, cantantes, músicos, compañías de operetas, bailarines y artistas de circo de origen germano llegaron a Buenos Aires atraídos por los festejos y algunos permanecieron, con suerte diversa, hasta que el estallido de la guerra en 1914 ensombreció el panorama general y agravó la situación de los que permanecían en Buenos Aires y no habían logrado una mínima estabilidad laboral

El auxilio a los artistas rara vez provenía de la elite local - muy aficionada a los grandes compositores clásicos alemanes - a la que más de una vez se recurrió, y que - paradójicamente - en muchas oportunidades constituía su público, pero que parecía prestar oídos sordos a sus tribulaciones fuera de los escenarios. La oligarquía argentina de la época, europeizante y con pretensiones de emular a la nobleza verdadera con la riqueza de sus estancias, no solía tener contactos sociales públicos con los cómicos. Hasta sus relaciones románticas fueron entonces mayoritariamente escandalosas y mantenidas en la clandestinidad, salvo contadas excepciones como la soprano portuguesa Regina Pacini, casada con el futuro presidente Marcelo T. de Alvear, y la española María Guerrero, casada con un legítimo aristócrata español y recibida en los salones de Buenos Aires. Un agudo comentario al respecto nos ha dejado el barón von der Goltz en sus recuerdos de viaje, Impresiones de mi viaje a Argentina, publicados en Berlín en 1910, donde manifestaba que

En mi vida no he debido ponerme tantas veces el uniforme de gala como durante las semanas festivas en la Argentina... en general en Buenos Aires se encuentra uno en una sociedad de rasgos muy aristocráticos y no, como se esperaría de un estado joven o de una colonia, en un mundo que todavía no ha llegado a esta altura de la cultura moderna (en Vior, 2015: 32).

También sería la misma sociedad caritativa germana para socorro de los enfermos y necesitados en nuestro país, la que auxilió a varios artistas de aquella procedencia cuando la noche del 19 de agosto de 1910 un trágico suceso conmocionaba la ciudad: la tradicional tienda A la ciudad de Londres - ubicada en la esquina de Perú y Victoria fue arrasada por un voraz incendio. El antiguo establecimiento donde se proveyeran varias generaciones de familias porteñas y las diferentes compañías teatrales nacionales y extranjeras compraban telas, plumas y accesorios para la confección de vestuarios, ardió hasta los cimientos en un siniestro de proporciones colosales. En los altos de la tienda funcionaba el Chester Hotel - donde solían hospedarse numerosos artistas - y varias oficinas comerciales y estudios jurídicos, que quedaron también devastados por la acción de las llamas y el agua. Tres alemanes y una austríaca que conformaban un cuarteto de artistas exóticos contratados por la empresa del Casino - que sólo hablaban alemán - además de perder sus pasaportes y todas sus pertenencias, incluyendo vestuario, pelucas, etc., sufrieron quemaduras leves y principio de asfixia. Abandonados por 
la empresa, fueron finalmente socorridos por sus propios compatriotas y una colecta organizada privadamente por Pablo Fabatz, quien en 1916 dirigiría la revista Germania, publicación de la colonia germana que circulara en español durante los años de la I Guerra Mundial. Carasy Caretas le dedicaba en su número 621 del 27 de agosto de 1910, cuatro páginas con impresionantes fotografías a la cobertura del siniestro e informaba que la casa Gathy Chaves resolvía dar trabajo a buen número de empleados que, por el desastre, habían quedadoen la calle y también sobre la suscripción entre la banca y el comercio en favor de los damnificados. Ni una palabra puede hallarse sobre los artistas.

También integró la otra cara de los festejos del Centenario el incendio del circo del célebre clown inglés Frank Brown ${ }^{1}$-en mayo de 1910, pocos días antes de los festejos centrales- ubicado en la calle Florida, provocado por "una patota de muchachos chauvinistas, de las que se hicieron famosas en el Buenos Aires de principio de siglo" y que dejara en situación precaria a numerosos artistas (Sosa Cordero, 1978: 34 -35).

Un valioso panorama de la precaria situación de los artistas extranjeros del período lo proporcionan los recuerdos de María Inés Mertens ${ }^{2}$, una de las hijas del prestigioso dramaturgo argentino, crítico teatral, cuentista, novelista, empresario teatral, periodista, fundador y primer director de la revista teatral Bambalinas y activo dirigente gremial de las asociaciones que nuclearon a los autores, Federico Mertens (1886-1960). Se refiere a una circunstancia casi desconocida en la vida pública de su padre: la generosa ayuda que este prestara a numerosos actores y músicos europeos que por distintas razones quedaban a la deriva en Buenos Aires, muchas veces llegados con contratos de palabra que no se cumplían, al margen de cualquier protección legal o sindical, sin medios de subsistencia y sin posibilidad de regresar a su patria. A fines de 1915, a punto de salir en gira por América, Mertens prestaba auxilio a dos artistas austriacos de varieté que, arribados a Buenos Aires con contrato de palabra, fueran estafados por el empresario y -ya sin recursos y sin hablar una palabra de españolechados de una pensión del barrio de Constitución, confiscándoseles un baúl con su ropa ante la falta de pago. Ambos hermanos, oriundos de Viena, habían sido rechazados en la legación austro-húngara al solicitar su repatriación alegando la libertad de ambos a la hora de elegir la profesión de saltimbanquis y al aceptar el contrato de palabra: la legación consideraba que esa libertad eximía al Imperio Austro Húngaro de obligación alguna de solventar sus pasajes de regreso en un carguero, pese a ser ambos ciudadanos de ese estado y estar en edad de reclutamiento militar en época de guerra. La ayuda de Mertens -dinero, contactos laborales con sus colegas, contacto con las distintas iglesias de la colonia alemana tanto luterana como católica, ubicación en pensiones o casas de familias conocidas- proporcionada silenciosamente, no sólo benefició a artistas de origen germánico -el propio padre de Mertens fue un inmigrante alemán afincado en el país- sino a todos los que lo necesitaran sin distinción de nacionalidades. También el popular dramaturgo Enrique García Velloso (1880 - 1938) solía ayudar generosa y discretamente a artistas españoles en desgracia.

\section{Las repercusiones de la I Guerra Mundial en los escenarios de Buenos Aires. Los artistas extranjeros y la guerra}

El contexto político del país todavía presenciaba el antagonismo entre el Estado y las ideologías que - como el Anarquismo - lo censuraban y rechazaban de plano, pese a las leyes de Residencia (1902) y de Defensa Social (1910). A raíz del profundo cambio

1 Frank Brown había nacido en Brighton, Inglaterra, en 1858. De vida aventurera y dilatada trayectoria en nuestro país, fue payaso, acróbata y empresario circense. Falleció en Buenos Aires el 9 de abril de 1943.

2 Agradezco la rica información y el acceso a los recuerdos de su padre a la Sra. María Inés Mertens, que concedió a la autora de este trabajo una larga serie de entrevistas en Buenos Aires en 2002. La señora Mertens falleció en Montevideo el 25 de enero de 2013, a los 95 años. 
traído por la reforma electoral de 1912 que instalaba el sufragio universal, secreto y obligatorio el radical Hipólito Irigoyen triunfaba en las elecciones nacionales.

Al estallar la I Guerra Mundial (1914 - 1918), el conflicto acaparó la atención de todas las clases sociales y de todas las tendencias políticas: la conflagración europea había conmocionado profundamente a Buenos Aires, donde casi todos - fruto de la masiva incorporación de inmigrantes - tenían familiares o amigos en el viejo continente. A todas horas, gran cantidad de gente se agolpaba ante las pizarras de los diarios para conocer los cablegramas con las últimas noticias. A la salida de los teatros los espectadores pasaban por La Nación y La Prensa para enterarse de las últimas informaciones de los frentes de batalla. La Argentina ocupaba un lugar destacado en el comercio mundial ya que figuraba entre los mayores clientes y proveedores de las principales naciones del mundo: era abastecedora de productos alimentarios y otras materias primas para los países europeos y estaba vinculada a ellos por estrechos lazos económicos, étnicos y culturales. En aquel momento el país mantenía relaciones amistosas y económicas con muchos de los países que ahora integraban bandos enemigos y era necesario definir su postura frente al conflicto.

El estallido de la guerra coincidía con el momento en que el sector mayoritario de las elites conservadoras - promotoras de la reforma electoral que adecuara el sistema político a las transformaciones demográficas y sociales - se vio desbordado por el resultado surgido de la misma y debió sufrir los embates de los sectores conservadores tradicionales, que intentaron infructuosamente recuperar el terreno perdido y frenar de esa manera el avance de la Unión Cívica Radical, partido que incluía a los sectores medios hijos de la inmigración.

El país tenía a Europa como principal fuente de riqueza en las exportaciones de sus productos, era lógico que se procurara que estas no se interrumpieran: la Argentina opta por la neutralidad. Si bien los lazos económicos mantenidos con Inglaterra eran los más fuertes, la posición de Alemania -sobre todo en algunos rubros del comercio, intercambio académico y tecnología - también era muy sólida, por lo que no existía un interés generalizado en entrar en conflicto con aquella nación. Existía una nítida mayoría favorable a la Entente Aliada, aun cuando la posición neutralista de la Argentina no estaba en discusión en líneas generales e importantes figuras de la elite fueron germanófilas - como Estanislao Zeballos, Belisario Roldán y Ernesto Quesada, entre otros muchos.

El campo teatral se vio profundamente afectado por la guerra tanto en Europa, convertida en un gran campo de batalla como por las consecuencias de la intervención del Estado que, en todos los bandos, estableció como prioridad reforzar el patriotismo de la población, elevar la moral, estigmatizar y ridiculizar al enemigo y fomentar la colaboración económica espontánea del público traducida en recaudación de fondos, compra de bonos de guerra y donaciones a los ejércitos en metálico y especie.

A través de las obras y espectáculos patrióticos y de recaudación de fondos para la Cruz Roja de todos los bandos, números vivos, cuadros alegóricos y la posibilidad de entretener a las tropas en los distintos frentes, los artistas tuvieron oportunidad de paliar en alguna medida su ya precaria situación laboral, agravada por el racionamiento de todas las economías de los países involucrados, el trastorno de los transportes y la obvia disminución del público.

Las dificultades para la supervivencia misma fueron creciendo: la guerra que entusiastamente habían recibido muchos europeos - esperanzados en una regeneración de la sociedad - no resultó lo breve que pueblos y gobiernos habían imaginado. A medida que avanzaban los cuatro sangrientos años que finalmente duraría, los frentes 
de batalla engullían multitudes: el teatro también se vio afectado por el reclutamiento tanto en los países que integraban la Entente aliada como las Potencias Centrales.

Ante el trágico panorama europeo en los primeros años de guerra, numerosas compañías emprendieron el cruce del océano rumbo a América - muchos de sus miembros masculinos para eludir el reclutamiento militar - algunas conociendo ya ruta y contexto por haber hecho antes giras por el Nuevo Mundo, y otras corriendo el riesgo de lo incierto de los tiempos y de la aventura.

Buenos Aires, importante metrópoli y capital de un país neutral, se convirtió en una codiciada plaza para los artistas extranjeros de la época, especialmente por la inmigración europea que constituía gran parte de su población y su influencia en la cultura local. Los escenarios porteños recibieron artistas de calidad y prestigio - así como otros ignotos - que veían en la capital sudamericana una especie de refugio casi europeo cuando sus países se habían convertido en campos de batalla, que les permitiría esperar a salvo la llegada de tiempos mejores. Al promediar el conflicto fue cada vez más peligrosa la navegación: la guerra marítima se intensificaba.

Las dificultades se reflejaban cada vez con mayor énfasis en la actividad teatral. Decía al respecto el cronista de "Teatros" de Fray Mocho que

La atención general sigue muy despegada de los teatros. Apresurémonos a manifestar nuestra sospecha de que en este fenómeno interviene la guerra europea con sus efectos financieros mucho más que con la fuerza del espectáculo sobre la atención pública. La época es mala: el año ha sido terrible; el éxodo de las troupes que han tenido que soportar el temporal reinante, parece una liberación. Podría pensarse - se siente esa impresión - que los teatros van a quedar vacíos y sonando a hueco por mucho rato $\left(\mathrm{N}^{\circ} 121,21\right.$ de agosto de 1914$)$.

Desde la perspectiva de las compañías nacionales, los riesgos de la guerra en el mar que impedían el arribo de las compañías extranjeras de gran cartel, favorecieron su acceso a las salas y actores locales se constituyeron como cabeza de compañías. El antes mencionado Federico Mertens (1948) opinaba en Fray Mocho que sin la guerra algunos de esos intérpretes habrían necesitado muchos años para alcanzar - aun mereciéndolo - tal posición.

El año 1917 significó un giro dramático para la ya peligrosa travesía por mar de las compañías y artistas que individualmente se atrevían a tomar el riesgo, ya que una nueva arma - casi experimental - se hace a la mar, triplicando los hundimientos: el submarino. Entre 1917 y 1918 la llamada guerra submarina a ultranza entre el Imperio Alemán y las potencias aliadas - en especial Inglaterra - además de hundir gran cantidad de barcos de ambos bandos, tuvo con frecuencia el daño colateral de mandar a pique a barcos de pasajeros y de países neutrales. Estas circunstancias trágicas se repetirían en la II Guerra Mundial: un ejemplo sería la muerte en 1942 de Fernando Díaz de Mendoza y Guerrero, hijo de los célebres actores españoles Fernando Díaz de Mendoza y María Guerrero, como resultado del hundimiento del barco mercante Monte Gorbea, en el trayecto de Buenos Aires a Bilbao - regresaba a España después de una temporada poco exitosa en Buenos Aires, dejando atrás y sin pagarles a los actores de su compañía - torpedeado aparentemente por error por un submarino alemán. Esto lo recuerda Nel Diago (1994) y también la prensa de la época señalando que "segundas partes nunca son buenas".

El Teatro Casino fue uno de los que más sacaría provecho de la afluencia de artistas extranjeros para sus funciones - jerarquía que decaerá después de la guerra - como 
la bailarina española Elvira Pujol, La Satanela, además de acróbatas, ventrílocuos, equilibristas, contorsionistas, mimos, bailarines, patinadores, luchadores, esgrimistas, etc.

Los artistas locales de la época ya afrontaban una situación laboral extremadamente precaria que daba lugar a una infinidad de abusos por parte de los empresarios: su libertad personal se veía sujeta a la omnipotente voluntad de los empresarios, la agobiante cantidad de funciones, la modalidad de los contratos de palabra que traía un sinnúmero de problemas, sueldos sobre los que se aplicaban constantes multas por faltas reales o no, la necesidad de proveerse su propio vestuario y la ausencia total de algún tipo de cobertura en caso de accidente o enfermedad, sumado a la inexistente protección sindical y al frecuente abandono de los artistas en las giras por parte de la empresa.

Para los artistas extranjeros la situación, además de precaria, muchas veces amenazaba literalmente su misma supervivencia. Numerosos artistas de todos los rubros no pudieron regresar a Europa, quedando varados en Buenos Aires, sin recursos, abandonados por empresarios y cabezas de compañías, sin una legislación laboral que protegiera mínimamente a los locales y mucho menos a los extranjeros, en muchos casos sin hablar español y rechazados por sus embajadas y consulados por su condición de comediantes, cómicos o saltimbanquis. La venta de sus vestuarios en locales de ropa usada o sastrerías teatrales - donde luego eran revendidos - para sobrevivir se tornó común, lo mismo que el empeño de joyas y distintos objetos de valor por parte de aquellos que las poseían.

El conflicto europeo conmovía a la sociedad argentina: había una fuerte influencia de la cultura francesa en las elites - durante toda la guerra fue común entonar la Marsellesa al inicio de las funciones teatrales - y en la moda, mientras los usos y costumbres tenían influencia inglesa.

La guerra teñía la política y los ánimos porteños: En 1916 ocupó la sala del Teatro Coliseo una compañía formada por cantantes venidos de Italia y elementos locales, encabezados por la soprano Adelina Agostinelli ya entonces radicada aquí. Les cadeaux de Noel de Xavier Leroux anunciada para ser presentada en el Teatro Colón por un elenco francés fue prohibida por la municipalidad de la Capital: las autoridades persistieron en su negativa, que se fundamentaba en el conflicto europeo en pleno desarrollo - la obra del compositor francés por su tema podía configurar un alegato antigermano cuando el país era neutral - y, confirmado el rechazo oficial, se realizó el estreno en el Teatro Solís de Montevideo el 20 de agosto con elenco del Colón. Tanto el gobierno de Victorino de la Plaza así como el de Yrigoyen triunfante ese mismo año, mantuvo férreamente la neutralidad, no obstante las reiteradas presiones de las potencias beligerantes. Se organizó entonces un viaje especial en el vapor Ciudad de Buenos Aires para los argentinos que deseaban ver la obra que nunca llegó a representarse en nuestro país.

En los años de la guerra, las tribulaciones laborales de los artistas tampoco disminuían acorde a lo prestigioso de su trayectoria. En 1916 llegaba a Buenos Aires una figura mundialmente famosa: Isadora Duncan. La bailarina californiana entonces de treinta y ocho años, arribaba al país en una primera visita, rodeada de un halo de polémica y de escándalo. Escándalo por su agitada vida sentimental y la terrible tragedia de la muerte en 1913 de sus hijos de tres y siete años en un accidente, y luego de un bebé recién nacido, y polémica por lo innovador y rupturista de su arte, rechazado - tanto como admirado - por muchos. Se decía que la desgracia ocurrida a sus hijos la había afectado irremediablemente: entre sus extravagancias se contaba la más absoluta despreocupación respecto del dinero, lo tuviera o no, además de 
un marcado desinterés por las convenciones sociales. Las primeras dificultades de su gira argentina aparecieron ya en el barco que la traía: las cortinas y alfombras que Isadora usaba en sus recitales no habían sido embarcadas y tuvo que encargar nuevas por un costo de U\$ 4.000. Isadora, al no disponer de efectivo, debió pagar a crédito. Las partituras orquestales de sus programas también estaban en viaje desde Francia y las reemplazó con la ayuda del director del Conservatorio de Buenos Aires. Pese casi no disponer de dinero, la artista se alojó en el Plaza Hotel. Los espectadores de su primer concierto - 12 de julio de 1916 - recibieron con frialdad la danza de Isadora: el público porteño estaba acostumbrado al ballet, aún en sus formas más innovadoras - el célebre bailarín ruso Vaslav Nijinsky se había presentado tres años antes con un éxito arrollador - y la técnica de la bailarina norteamericana fue hallada pobre y limitada. La víspera del segundo concierto Isadora fue con un grupo de amigos a un club nocturno e impulsada por la concurrencia que la reconoció, bailó el Himno Nacional envuelta en una bandera argentina. Al día siguiente, el gerente del Teatro Coliseo adujo que ella había faltado al contrato con él al ofrecer esa actuación imprevista y decidía rescindir unilateralmente el mismo. Sería necesaria la intervención de Maurice Dumesnil, director musical de la gira, para que el gerente desistiera de su decisión. Sin embargo, otras dificultades se avecinaban: Isadora quería dedicar a Wagner su programa y su director musical que era francés se negó a cooperar. Dumesnil estaba de licencia del ejército francés y pensó que sería censurado si en tiempo de guerra participaba de un programa con obras de un compositor alemán. Pero, aunque consiguieron otro director, el programa wagneriano alejó a mucho público, del mismo modo que los alemanes se vieron afectados por su interpretación de la Marsellesa. Durante el concierto, algunos espectadores comenzaron a hablar en voz alta, Isadora dejó de bailar y se dirigió a ellos airada, diciendo que ya le habían advertido que "los sudamericanos no entendían nada de arte" agregando: "ustedes no son más que unos negros", lo cual provocó un comprensible tumulto y se suspendió la función. Este acontecimiento determinó que el administrador cancelara las funciones restantes. Antes de partir a Montevideo, Isadora, en bancarrota, sin haber cobrado el resto del contrato, tuvo que dejar su abrigo de armiño y sus pendientes de esmeralda como garantía de pago del hotel, que no podría cubrir. Habían sido regalo de su ex amante Paris Singer, heredero del imperio de las máquinas de coser, quien había financiado muchas de sus aventuras artísticas. En 1927, en Niza, agotada y sin recursos, subió a un auto deportivo manejado por un joven chofer italiano y murió ahorcada por su chalina, enganchada en la rueda de la Bugatti. (Véanse la autobiografía de Isadora Duncan publicada en Niza el año de su muerte con múltiples reediciones posteriores, y, en la prensa argentina de 1916, las repercusiones del incidente).

A fines de 1918 - el último año de guerra - a la castigada situación de los artistas en Buenos Aires, se agregaba una persistente epidemia de gripe especialmente grave, que traía al que la contraía serias complicaciones respiratorias: se decía que era la misma gripe española que diezmara los campos de batalla europeos. La epidemia hizo estragos en los elencos teatrales y, sobre todo, entre las tonadilleras procedentes de España, que estaban casi todas enfermas y para las que los elencos organizaran distintas colectas. La Revista Popular - dirigida por el escritor y periodista Juan José de Soiza Reilly, quién en 1914 embarcara hacia el conflicto europeo como corresponsal de guerra - recogía los avatares de la epidemia en los teatros a través de varios artículos en noviembre de 1918 y fue uno de los organizadores de las colectas. En 1914 partían numerosos reservistas franceses hacia el frente en Europa, a bordo del vapor Lutetia, despedidos en el puerto por las compañías francesas que no habían podido conseguir pasajes para retornar a su país. 


\section{De lo que no habla la gente decente. El agravante de la extranjería en la indefensión de las mujeres en el campo teatral finisecular}

La problemática de la mujer en el mercado laboral remunerado y extra doméstico permaneció siempre en el corazón de los debates sociales que alimentaban las crecientes esferas públicas urbanas desde las publicaciones periódicas hasta las cátedras y los púlpitos de las de las sociedades de discusión de las burguesías urbanas: los diversos proyectos liberales excluían a las mujeres como posibles sujetos de derechos (Burguera, 2006: 293-297).

Un panorama de las conclusiones de los propios congresos obreros durante el período 1890 - 1921 - en el contexto del movimiento obrero argentino y el trabajo femenino - revela a través de sus declaraciones o resoluciones tres tipos de reacciones ante el problema del trabajo de las mujeres: 1) se lo consideraba impropio de las mujeres: el hombre debía percibir una remuneración suficiente que cubriera las necesidades de supervivencia y reproducción de la familia, 2) se lo percibía como una competencia ruinosa para el salario y /o nivel de ocupación masculino, 3) la sobreexplotación de la mujer terminaría provocando la degeneración de la raza, imposibilitando la reproducción de una clase obrera sana. El verdadero lugar de la mujer obrera era su hogar y sus actividades naturales eran la crianza y educación de los niños y el trabajo doméstico (Nari, 1994: 266).

Párrafo aparte merece la situación de las mujeres en los escenarios de la época. La artista - especialmente la extranjera - era por antonomasia sujeto de la vulnerabilidad más grave, peligrosa y silenciada. No solamente estaba inmersa en la misma indefensión laboral que sus colegas varones, sino que padecía además los prejuicios de la sociedad patriarcal de la época respecto a la inferioridad intelectual y física del sexo femenino, sumado a la censura moral que su actividad generaba en la gente decente.

Más que por escrito - las denuncias por los casos de abuso en el medio artístico de la época eran prácticamente inexistentes - es la memoria oral a la que hay que recurrir para tener apenas una mirada - la punta de un gran iceberg - de la naturalización de estos incidentes para las víctimas, los victimarios y el resto de la sociedad, incluida la Justicia. La asociación de las mujeres en el teatro - y en el circo - con la prostitución, persiste hasta nuestros días; en aquellos tiempos, era un concepto internalizado por todas las clases sociales y las distintas estructuras del Estado.

De la revisión de las órdenes del día de la Policía Federal del período, las denuncias radicadas por delitos cometidos en el ámbito teatral en los que están involucrados artistas extranjeros se refieren a riñas, hurtos o tumultos que los tienen como supuestos perpetradores. Las únicas denuncias que involucran a mujeres extranjeras relacionadas al teatro son aquellas en las que son acusadas por padres o tutores, ya radicados en el país, de fugarse para unirse a cómicos, saltimbanquis o al circo. No se encuentra constancia de ninguna en las que se denuncie un abuso ni sexual, físico ni de ninguna especie.

Basta constatar la cantidad de menores de edad que llegaban y partían en distintas compañías, cruzando el océano sin padres o tutores, con una situación confusa respecto a la patria potestad, desconociendo el idioma, totalmente dependientes de cabezas de compañías o empresarios, sumado a la falta de protección por parte de las leyes de los países a los que llegaban en tránsito y por parte de sus propias legaciones diplomáticas, para inferir - con basamento en numerosos testimonios y en la memoria oral del medio - que la situación real sería diametralmente opuesta. 
Los recuerdos de María Inés Mertens sobre un secreto a voces durante las primeras décadas del siglo XX, develan un aspecto de aquella situación: la práctica padecida por numerosas artistas nacionales y - sobre todo extranjeras - que no gozaban de una popularidad o prestigio que las protegiera, de ir a daruna vuelta con el empresario en uno de los coches cerrados de alquiler de la época, en el que otorgaban ciertos favores sexuales si estaban interesadas en mantener su trabajo, obtener algún destaque, mejorar su cachet, ser incluidas en alguna gira, etc. Esta difundida práctica sumó a lo triste lo tragicómico, cuando en julio de 1910 se hacía obligatorio la incorporación del reloj taxímetro en todos los vehículos tanto de tracción a sangre como mecánica (Parapugna, 1980: 172-173): al correr el reloj y elevarse la tarifa del viaje, el paseo fue mucho más corto. Primero los cocheros y luego los choferes de taxi de la época conocieron muy bien esta práctica, y recibían generosas propinas de los empresarios por conducir sin verni oír nada más que el tránsito.

Buenos Aires fue durante muchos años plaza obligada en las giras teatrales de la célebre pareja María Guerrero y Fernando Díaz de Mendoza que cosecharan grandes éxitos en nuestro país y fundaran el Teatro Nacional Cervantes. Mertens fue admirador y constante espectador de las funciones de la compañía, así como uno de los organizadores de los numerosos homenajes que las sociedades de autores ofrecieran a los actores. También sería testigo del fastuoso tren de vida que el matrimonio llevaba durante sus giras y de varios enfrentamientos entre ambos en camarines, debido al donjuanismo de don Fernando Díaz de Mendoza, al que se decía padre de varios hijos ilegítimos. Entre los episodios conocidos respecto a las aventuras extramatrimoniales del actor, la joven actriz Catalina Bárcena daría a luz a un hijo de Díaz de Mendoza llamado Fernando como su padre biológico - y para evitar el escándalo, se concertó su casamiento con el actor Ricardo Vargas, también miembro de la compañía, quien reconoció al niño en 1909. Era un rumor permanente entre la gente de teatro de la época la predilección de don Fernando por jovencísimas actrices, que nunca faltaban en las giras de la compañía y que en más de un caso volvían embarazadas a España. También recordaba María Inés Mertens las simpatías de Femando Díaz de Mendoza por la Liga Patriótica Argentina, un grupo político argentino promotor del nacionalismo de derecha, fundado en 1919 por Manuel Carlés en ocasión de la tristemente célebre Semana Trágica entre el 7 y el 14 de enero de 1919 en Buenos Aires.

De igual gravedad fueron los numerosos incidentes en los que se agregaba al acoso, la discriminación y el abierto racismo. Un ejemplo de esto fue lo padecido en 1929 por la célebre artista afroamericana Josephine Baker (1906 - 1975) - la "Venus de ébano" - al arribar en gira al puerto de Buenos Aires y serle tomadas las huellas digitales, encontrarse con afiches que la tildaban de escandalosa y mujer fatal, y recibir, junto a las críticas favorables, otras demoledoras en nombre de las buenas costumbres. $\mathrm{Al}$ decir de Octavio Ramírez (1963: 655 - 657) - crítico de La Nación - el arte exótico de la Baker era "extraño, negro y desconcertante pero en su género instintivo, salvaje y fuerte" y señalaba la sorpresa del público al final, al cantar ella el tango Haragán con pronunciación sajona y gestos de arrabal; concluía opinando que su arte era "un pedazo de selva acelerado por un motor americano". Especial atención merece el racismo explícito de la revista teatral Comoedia - que comenzó a publicarse en Buenos Aires el 1 de abril de 1926 - que en su número 54 del 1 de octubre de 1929 señalaba que "todo el arte emotivo de esta negra epiléptica está hecho con ritmo de mono, el animal más parecido al negro", y que ella misma era "una mona a la que un cazador moderno le ha ubicado un manojo de plumas en el mismo sitio en que tenía un rabo prensil y peludo"; remataba opinando que Josephine Baker era solamente "un cuerpo hermoso y lustroso que se sacude grosera y desenfrenadamente al son candombero de otros negros que soplan con aire simiesco". 
El clima político del país no escapaba al de la época: ante el crecimiento de una incipiente extrema derecha, principalmente de clase alta, se vio a los extranjeros y a los izquierdistas como amenazas interconectadas, el carácter preponderantemente foráneo de la clase trabajadora y la composición criolla de la clase alta posibilitaron esta asociación. En consonancia con el contexto histórico de la ultra derecha en ascenso en el viejo continente - que llevaría a la tragedia de la II Guerra Mundial - la célebre artista afroamericana fue atacada también en varias ciudades europeas por miembros de círculos racistas, como en Viena donde grupos nazis la agreden verbalmente. En Buenos Aires, según sus recuerdos, "el presidente Yrigoyen toma partido contra mí en el diario La Calle y sus adversarios aprovechan para responderle en Crítica (Pujol, 1994: 202)" (Seibel, 2002: 719).

El hecho de haberse radicado en el país no protegió a la conocida declamadora Berta Singerman, de trayectoria nacional e internacional, de ser agraviada en Comoedia - en el mismo año 1929 - en términos antisemitas por una serie de artículos anónimos, comenzando por el titulado "Liquidemos el bluff de Berta Singerman", donde el articulista señalando el fracaso de la artista en Europa, informaba que ya estaba otra vez en Buenos Aires "esta judía que con sus denuestos niega el talento de sus hermanos de sangre" y de la que "los europeos se rieron al verla agitar sus huesudos brazos como molinetes y ladrar las poesías de sus víctimas". En la misma tesitura, al año siguiente con la firma de D`Artagnan, se afirmaba que "Berta Singerman de Stolek, nacida en Rusia en 1901, sostiene que se nacionalizó argentina, pero su raza - respetable y hasta admirable - es impermeable a todo lo que pueda constituir sentimientos nacionales, hábitos, tradiciones e impulsos argentinos" (Comoedia, año IV, $\mathrm{N}^{\circ} 55,1^{\circ}$ de noviembre de 1929).

La revista también agredió y denigró a lo largo de la década del veinte a la conocida cancionista Azucena Maizani en artículos sin firma o con seudónimo: en su número 5, del 1 de junio de 1926, era la "ex famosa cancionista de tangos hoy en plena decadencia", "corpulenta, maciza, torpe" que "cobra un sueldo indecente"; en el número 42, del 1 de octubre de 1928, se la señalaba como un "ídolo que se derrumba y ya no existe" porque "no queda ni el recuerdo de su adiposa figura de burguesa salchichera".

Si se tiene en cuenta que el staff de Comoedia estaba integrado - entre redactores y colaboradores - por figuras del nuestro campo teatral tan reconocidas como José J. Berrutti, Armando Discépolo, José González Castillo, Alberto Vaccarezza, Ernesto de La Guardia, Claudio Martínez Paiva, José Antonio Saldías, Roberto Tàlice y Francisco De Filippis Novoa - entre muchos otros que escribían también en Caras y Caretas, Fray Mocho, PBT, Revista Popular y otros magazines de la época argentinos y uruguayos - asombra, aún en el clima político de aquel momento, la virulencia de los términos racistas y descalificadores empleados contra las artistas integrantes de ese mismo campo, hoy en día impensables.

\section{A modo de conclusión}

En aquellos tiempos anteriores a la actual legislación laboral que - con todas sus falencias - construyeron al trabajador como sujeto de derechos específicos, los contratos se regían por el derecho civil. Sin embargo, aún para aquellos artistas extranjeros cuya situación laboral estuviera enmarcada en uno de esos instrumentos, rara vez significaba protección concreta ante incumplimiento de sus cláusulas por parte del empleador.

Muchos de los artistas extranjeros más reconocidos eran contactados por representantes o apoderados de los empresarios teatrales - o por estos mismos personalmente 
- que viajaban a Europa, y los contratos se negociaban y firmaban en los distintos países del viejo mundo. Al arribar al país era frecuente el incumplimiento de cláusulas, modalidades de trabajo diferentes a lo pactado, falta de pago, etc. Entonces se acentuaba la vulnerabilidad del artista extranjero, dado que - según nuestro derecho civil - los contratos firmados fuera del territorio de la República, eran juzgados en cuanto a su validez o nulidad, su naturaleza y las obligaciones que produjeren, por las leyes del lugar en que hubiesen sido celebrados.

Ante cualquier problema relacionado con alguna faceta del trabajo del artista - despido injustificado, cantidad extenuante de funciones, situaciones de alto riesgo, accidentes, falta de pago, multas constantes, horarios imposibles, condiciones insalubres del alojamiento o ninguno, cancelación intempestiva de funciones, abandono en las giras, mal trato o abusos de cualquier tipo, etc.- el recurso a la asesoría jurídica letrada era prácticamente inexistente para la gran mayoría. A la indefensión del artista extranjero - en especial en el varieté - contribuía generalmente su aislamiento en la sociedad receptora por el idioma, la trashumancia, los prejuicios raciales, la política del momento - a qué bando pertenecía su país de origen ante las guerras - y la falta general de respuesta de legaciones diplomáticas ante pedidos de ayuda de sus ciudadanos cuando éstos eran cómicos.

De los pocos pedidos de repatriación de artistas que caían en la indigencia - por cualquier razón - en nuestro país en el período, no hay registros conocidos y casi tampoco noticias, más que por testimonios orales: no sólo eran rechazados verbalmente la mayoría, sino prácticamente no quedaban registrados al ser estos atendidos por personal subalterno que, la mayoría de las veces, despedía sin contemplaciones al peticionario (María Inés Mertens, entrevista realizada en octubre 2002, en Buenos Aires). Según dichos de algunos de los perjudicados (Ibídem) - artistas de varieté como ventrílocuos, contorsionistas y transformistas- los funcionarios de las embajadas y consulados de los distintos países europeos destacaban la libertad del artista a la hora de firmar el contrato - aquellos que lo tenían por escrito - y no pocas veces la de haber elegido semejante oficio, para concluir que su gobierno no tenía obligación de cargar con los gastos que implicaba su repatriación. En algunos pocos casos - aunque no en todos - la situación variaba en tiempos de guerra para los varones en edad militar que fueran aptos para ser reclutados para el frente.

La situación era tal, que en algunos casos rozaba literalmente la servidumbre, tipificada en nuestro actual código penal como uno de los delitos contra la libertad individual y aplicándose a los perpetradores penas de tres a quince años de prisión o reclusión, no sólo al que "redujere a una persona a servidumbre o a otra condición análoga", sino "al que la recibiere en tal condición para mantenerla en ella" (Código Penal de la Nación Argentina, Art. 140).

Pese a poder presumirse que los artistas del período - extranjeros y locales - que firmaban contratos con pleno conocimiento, no lo hacían bajo coacción física o moral, la desigualdad de su situación entre ellos y la empresa era de tal magnitud - como el contexto de aislamiento o de abierta hostilidad que a veces enfrentaban - al carecer de poder de negociación, teniendo como única alternativa no contratar, que esa unilateralidad recordaría más las características del contrato poradhesión.

La modalidad del contrato poradhesión es aquella por la cual "uno de los contratantes adhiere a cláusulas generales predispuestas unilateralmente por la otra parte o por un tercero sin que el adherente haya participado en su redacción" (Código Civily Comercial de la República Argentina, Arts. 984 a 989). Es decir que no son acuerdos negociados y una de las partes se limita a aceptar o rechazar sus cláusulas sin poder modificarlas, y por lo general -entonces y hoy en día - devienen en un peligroso mecanismo jurídico 
que suele ocasionar múltiples abusos. En la actualidad está legislada la protección contra las cláusulas abusivas que importan la renuncia y restricción de los derechos del adherente.

También contribuyó a la precaria situación de artistas nacionales y extranjeros la poca identificación de los mismos con los trabajadores en general, la percepción de sí mismos cumpliendo una suerte de sacerdocio a través de un don especial (Véase Mauro, 2015). Esa mirada sobre su profesión y su rol en la sociedad, impidió muchas veces que en épocas de necesidad y miseria producidas por calamidades propias o de su contexto histórico, consideraran denigrante dedicarse siquiera momentáneamente a otra actividad. En el caso de que, ante la situación apremiante, no tuviesen más remedio, se trataba de mantenerlo oculto considerándolo humillante.

Las revistas del tipo magazine del período como Caras y Caretas y Fray Mocho - por su mismo formato que privilegiaba la imagen- proporcionan apenas una pista sobre tantos artistas extranjeros que arribaron a nuestro territorio: la mayoría de las veces apenas un epígrafe bajo una foto, con sus nombres individuales de escena o los de sus troupes y el teatro en que actuaban. Sin embargo, la mayoría de las veces constituyen casi el único registro de sus presencias, que permite comenzar a indagar sobre las peripecias que como artistas y seres humanos padecieron en estas tierras. Esa era la cara oculta del trabajo del artista local y - especialmente - extranjero, que el público no veía ni le interesaba ver.

Al considerar al artista como trabajador, es insoslayable contemplar, en el período abarcado entre 1900 y 1920 en Buenos Aires, la situación de los extranjeros. Baste recordar las palabras que el escritor y periodista francés Albert Londres, ${ }^{3}$ dedicara a nuestra ciudad en su obra de 1927, El camino de Buenos Aires. La trata de blancas:

Los hierros, las maquinarias, las puntas de los cascos eran alemanes. Los ferrocarriles, los trajes y los pepinillos eran ingleses. Los automóviles, las navajas de afeitar y la mala educación eran yanquis. El barrendero era italiano. El mozo de comedor era español y el lustrador era sirio. Las prostitutas eran francesas. 


\section{Bibliografía}

》Burguera, M. (2006). "El ámbito de los discursos: reformismo social y surgimiento de la mujer trabajadora”. En Morant, I. (Dir.). Historia de las Mujeres en España y América Latina del siglo XIX a los umbrales del XX. Madrid: Cátedra.

»Diago, N. (1994). "Buenos Aires: la capital teatral de España en la Argentina (1936 1939)". En Pellettieri, O. (Ed.). De Lope de Vega a Roberto Cossa. (pp. 68 72). Buenos Aires: Galerna.

»Duncan, I. (2016 [1927]). Mi vida. Buenos Aires: Losada.

»Eujanian, A.C. (1999). Historia de Revistas Argentinas 1900 -1950. La conquista del público. Buenos Aires: Asociación Argentina de Editores de Revistas.

»Gutman, M. (2011). Buenos Aires. El poder de la anticipación. Imágenes itinerantes del futuro metropolitano en el primer Centenario. Buenos Aires.: Infinito.

"Lobato, M. Z. (2000). "Los trabajadores en la era del Progreso". En AA. VV. Nueva Historia Argentina. Buenos Aires: Sudamericana.

》Londres, A. (2008 [1927]). El camino de Buenos Aires. La trata de blancas. Buenos Aires.: Libros del Zorzal.

» Lutge, W., Hoffmann, W. y otros (2017). Los alemanes en la Argentina. 500 años de historia. Rohland de Langbehn, R. (Ed.). Buenos Aires.: Biblos.

»Mauro, K. (2015). ¿Trabajadores o Militantes de la cultura? En Congreso nacional de Estudios del Trabajo. El trabajo en su laberinto. Viejos y nuevos desafíos. Buenos Aires, [en línea. Consultado en www.aset.org.ar ]

" Mertens, F. (1948). Confidencias de un hombre de teatro. 50 años de vida escénica. Buenos Aires: Nos.

» Nari, M. M. A. (1994). "El movimiento obrero y el trabajo femenino. Un análisis de los congresos obreros durante el período 1890 - 1921". En Knecher, L. y Panaia, M. (Comp.). La mitad del país. La mujer en la sociedad argentina. (pp.259 -267). Buenos Aires: Centro Editor de América Latina.

»Parapugna, A. (1980). Historia de los coches de alquiler en Buenos Aires. Buenos Aires: Corregidor.

»Pellettieri, O. (Ed.) (1994). De Lope de Vega a Roberto Cossa. Buenos Aires: Galerna.

» Pujol, S. (1994). Valentino en Buenos Aires. Los años 20 y el espectáculo. Buenos Aires: Emecé.

》Ramírez, O. (1963). Treinta años de teatro 1925 - 1955. Buenos Aires: El Ateneo.

»Rogers, G. (2008). Caras y Caretas. Cultura, política y espectáculo en los inicios del siglo XX argentino. Buenos Aires: EDULP.

"Rufinelli, J. (1968). La revista Caras y Caretas. Buenos Aires: Galerna.

» Saint Sauveur Henn, A. (2017). “Carácter y peripecias de la inmigración alemana en la Argentina". En Rohland de Langben, R. (Ed.). Cuadernos del Archivo, Año I, № 1, (pp. 14 - 27). Potsdam: DIHA (Dokumentationszentrum der deutschspragige Inmigration nach Argentinien).

»Seibel, B. (2002). Historia del Teatro Argentino. Desde los rituales hasta 1930. Bue- 
nos Aires: Corregidor.

»Sosa Cordero, A. (1978). Historia de las Varietés en Buenos Aires (1900 - 1925). Buenos. Aires: Corregidor.

»Vior, E. (Ed.) (2015). Von der Goltz, W.C. Impresiones de mi viaje a Argentina en 1910. Buenos Aires: Ares.

"Zubieta, E. (2004). "Representar y polemizar: el humor de Caras y Caretas en el Centenario". En Biagini, H. y Roig, A. (Dir.). El pensamiento alternativo en la Argentina del siglo XX. (pp. 507-525). Buenos Aires: Biblos.

\section{Revistas}

》 Caras y Caretas (1900 - 1920).

»Comoedia (1926 - 1929).

» Fray Mocho (1900 - 1920).

» La Revista Popular (1918), Vol. II, № 36. 